\title{
Case Study: Kaospilots-From Passive Listeners to Global Change Agents
}

\author{
Jenna Lähdemäki
}

\section{INTRODUCTION}

Designing Your Life is one of the most popular courses at Stanford University (Kurutz 2016). It applies design thinking to life's big questions like 'what am I going to be when I grow up?' The course gives students tools to understand their own motives and aspirations. For many people, it would appear or seem not very good at answering the question of what would be a fulfilling career and life path for them. To that end, many make life decisions based on their own expectations towards themselves ('I have to become successful and successful to me means becoming a lawyer') or based on someone else's expectations (e.g. 'my mother has always hoped I become a dentist') (Fig. 12.1).

Kaospilot answers partly the same question as Designing Your Life does. There are too many university students who have struggled their way to the major they think is the answer to their dream career path, and then feel disappointed for reasons they might not know how to explain. This usually has to do with the lack of focus in personal

\section{J. Lähdemäki ( $\square)$}

The Finnish Innovation Fund, Sitra, Helsinki, Finland e-mail: Jenna.Lahdemaki@sitra.fi

(C) The Author(s) 2019

J. W. Cook (ed.), Sustainability, Human Well-Being, and the Future of Education, https://doi.org/10.1007/978-3-319-78580-6_12 


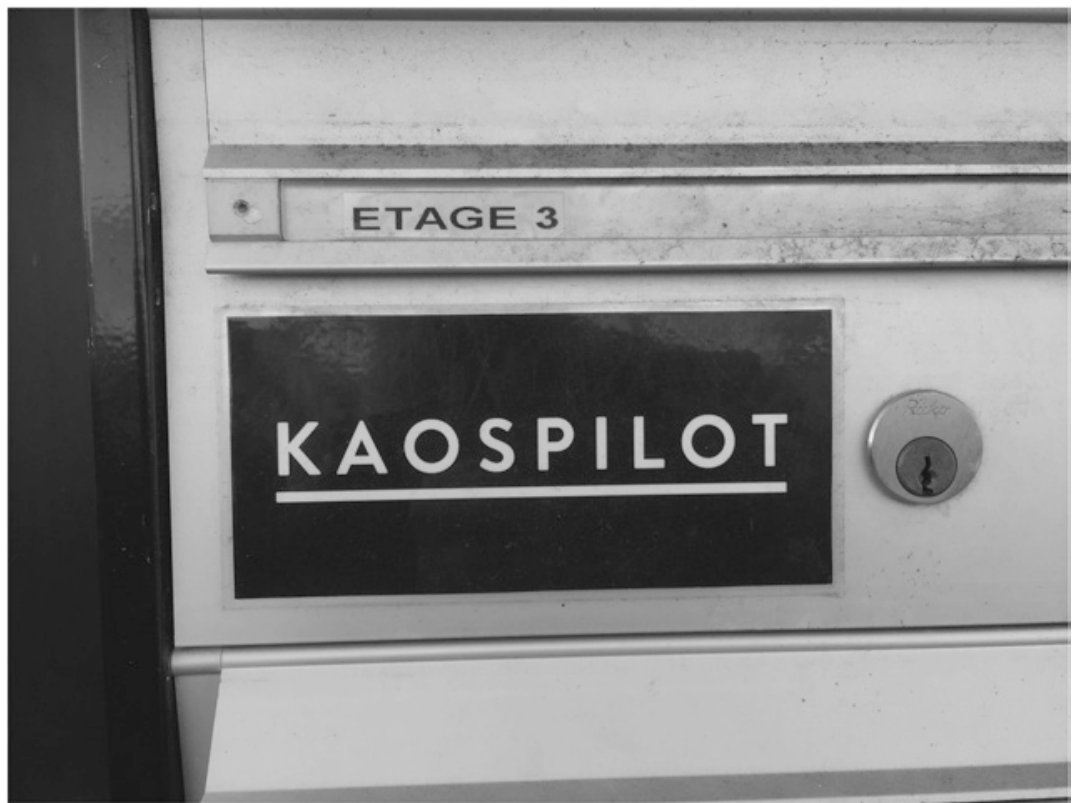

Fig. 12.1 Kaospilot mailbox at the school building in Aarhus, Denmark

development and self-reflection, both from an individual perspective and in terms of the teaching given from educational institutions. Students don't know how to articulate what they have learned, or their area of expertise and their strengths.

Furthermore, the job market is becoming increasingly insecure and entry-level positions are relatively rare. Many recently graduated people have difficulties finding a job that can both pay the rent and give them the requisite meaning and challenges. The Economist article 'Young, Gifted and Held Back' (2016) describes the consequences:

For the first time in history, the world's youngsters form a common culture, so they also share the same youthful grievances. Around the world, young people gripe that it is too hard to find a job and a place to live, and that the path to adulthood has grown longer and more complicated. Today's under-30s will one day dominate the labour force. If their skills are not developed, they will be less productive than they could be. (para. 3) 
One part of this puzzle is the question of how higher education prepares young adults to face an uncertain job market and ever more complex societies. There is a clear need for alternative education programs that give students the tools, networks and experience, and then empower individuals, grow their self-confidence and their faith in the future. Having theoretical knowledge is simply not enough.

Alongside Kaospilot, there are many other successful alternative education courses where an underlying theme is nurturing of capacities and competencies that allow a person to create their own job with an installed 'meaning'. One notable course is the 10-week Global Solutions Program $^{1}$ offered by Singularity University, where participants from about 45 countries study the world's biggest challenges, like poverty and climate change, and create solutions to battle these challenges with the help of exponential technologies, like AI and robotics.

Singularity University was founded by research scientists Ray Kurzweil and Peter Diamandis and is located in the NASA Research Park in California's Silicon Valley. The summer course has given birth to numerous interesting companies like Iris AI, involved with the ground-breaking use of scientific knowledge, and companies focusing on the development of resuscitation technology such as Neurescue used in cases of cardiac arrest.

For this case study, we will focus on Kaospilot, an entrepreneurship and design school located in Aarhus, Denmark.

The Finnish Innovation Fund, Sitra, has been working with the vision of creating a sustainable well-being society. Sustainable well-being refers to the pursuit of a 'good life' within the earth's carrying capacity. This means that well-being is addressed in a holistic way and that humanity is consequently adjusting to the planetary boundaries. The other principles of a sustainable well-being society are in the empowering of individuals and communities, moving to a regenerative and collaborative economy, building competencies for a complex world, and developing inclusive and adaptive governance. When I visited Kaospilot in Aarhus, I was interested in terms of both 'if' and 'how' the Kaospilot education could take these myriad themes into account. For this is a school that teaches students to say, 'I can change the world'.

\section{What Is KaOspilot?}

The world is not short of challenges, or opportunities. What we need are people who can create new solutions and act with empathy within complex and turbulent situations. (Excerpt from Kaospilot mission statement) 
Kaospilot is a hybrid business and design school with a strong emphasis on entrepreneurship. The Kaospilot programme is centred on teaching 'change makers' the ability to both navigate their way through uncertainty and to use it to their advantage, and to also embrace the opportunities presented by uncertainty and complexity. There is one other Kaospilot school in Bern, Switzerland that has a similar program and curriculum to the Aarhus school, though both schools have local adaptations.

Kaospilot was founded in 1991 by Uffe Elbaek, Thomas Heide and Gitte Madsen. Elbaek left the school in 2006 to serve as the Danish Minister of Culture from 2011 to 2012. Elbaek can variously be described as an author, entrepreneur, politician and political leader. Currently, he is a Member of the Danish Parliament for the Alternative party. He is the founder and leader of Alternative-a party that states it is against economic growth as the only economic path and instead works towards 'sustainable transition, a new political culture and the entrepreneurial creative power of society and individuals' (What is the Alternative 2017). Following the departure of Elbaek, Christer Windelow-Lidzelius, a former Kaospilot graduate, became the principal of the school in 2006.

Education at Kaospilot is rooted in action rather than theory. Students are evaluated on the basis of four criteria, which also serve as the objectives of education: to create deep meaning with others, improve themselves as change makers, develop and foster their personalities, and co-operate with their local community. Kaospilot is single-minded in its pursuit: to be the best school for the world, with a focus on social change, creative entrepreneurship and personal growth.

The school's three-year program, combining leadership, business design and project and process design, is equivalent to a bachelor's degree in scope, but in other respects, is very different from traditional studies at higher education institutions. Kaospilot is a private education institution that is partly financed by the state. This means that the there is no accreditation for the Kaospilot diploma. Many universities still consider it a bachelor's degree when students apply to master's degree programs. Admission requirements to Kaospilot consist of written application and an in-person workshop.

The studies comprise working on projects with clients and a four-month study period abroad, during which the students work on a change target chosen together with the local community. The final year of studies is fully focused on the individual student's own business idea and personal project. 
'The premise here at Kaospilot is not really to help us find career employment, but rather that we create our own jobs and perhaps employ a few others in the process' (Anu Paajanen, personal communication, October 2015) says Anu Paajanen, who was the only Finnish student at the school at the time of this writing.

Students are required to pay a fee to study at Kaospilot and only 38 students are admitted each year. Nevertheless, according to the Head of International Development and Education Design, Simon Kavanagh, compared to an average higher education institution, the school has fewer teachers in relation to the number of students. For Kavanagh, this proves that traditional education institutions can and should focus their energy on improving the student-faculty relationships so that students do not feel neglected. That said, the main responsibility with regards to learning and development always rests on the shoulders of the students. Kavanagh stresses:

It all starts with creating a close-knit community in which the students are responsible for their own learning, while knowing that assistance is available, provided by the team leaders and other staff, whenever necessary. We care about every one of our students. (Simon Kavanagh, personal communication, October 2015)

Alumnus David Jul adds:

Most of the educational institutions give you a diploma on the last day of your studies and then you are a graduate and can call yourself an engineer, for example. At Kaospilot, you are seen as a professional from day one and you also work with the clients starting the very first autumn of studies. It gives you a sense of belonging and ownership. (David Jul, personal communication, October 2015)

\section{KaOspilot-The Basics}

- Kaospilot was founded in 1991 by Uffe Elbaek and partners.

- 38 new students start Kaospilot studies every autumn.

- There are around 110 students studying each year in total.

- Average age of a Kaospilot student beginning studies is 24. You can apply only after turning 21-years old.

- Kaospilot is a private school and the cost of the 3 -year education is EUR 20,000. 
- $50 \%$ of the students come from Denmark, $25 \%$ from other Scandinavian countries and $25 \%$ from other countries.

- Around one third of the schools funding comes from the Danish Ministry of Science, one third comes from the student's tuition payments and the final third is financed by Kaospilot's consultancy's profits.

- According to an alumni study made by Kaospilot, 97\% of Kaospilot's graduates are employed two years after graduation. According to Eurostat, the overall employment rate for higher education was $83.7 \%$ in 2014 (Eurostat 2014). The OECD average employment rate for working age population (15-64 years) is $67 \%$. In Denmark, the figure is $75 \%$ (OECD).

\section{The Story-Why Was There a Need for a Kaospilot EDUCATION?}

A project that was totally devoid of realism. (Windeløv-Lidzélius 2012)

In 1989, two years before the Soviet Union collapsed, the founder of Kaospilot, Uffe Elbaek, and his colleagues from the Frontrunners (Kaospilots' predecessor) wanted to do something radical. They decided to organise a rock concert in Moscow's famous Red Square. Elbaek and colleagues wanted to foster solidarity, peace and a sense of belonging between Danish and Russian youngsters. The project was called The Next Stop Soviet. The Danish group wished to show that world politics and relationships between individuals were two separate issues, and that young people were similar on both sides of the iron curtain.

However, the Next Stop Soviet project team were not able to organise the rock concert in the middle of the Red Square as planned and had to settle for a more remote and consequently less high-profile spot on the periphery of Red Square. Despite the small setback, the concert was organised and the team received a cheerful welcome home when they returned to Denmark. They had done something extraordinary, something that had caught the public attention. Kavanagh explains, 'This also had to do with bigger trends at the time: hierarchies between adults and younger people were slowly fading away. Now young people were seen as active agents at the societal level' (Simon Kavanagh, personal communication, October 2015). 
Even though the rock concert in Moscow was seen as a spectacular success, financially the organising group were left with debts of 150,000 Danish Krone (approx. EUR 20,000/USD 23,000). As a result, the group started working with similar kinds of community projects in Denmark in order to pay back the debt. These different projects garnered notable visibility and finally caught the attention of the then leftist government. Politicians in power thought, in short, that the group's work was valuable and should be supported.

Together with the government backed support and other converging events, in 1991, Kaospilot was established. Incentives that led to the founding of the school included the ideas that in 1991 the founders (Uffe Elbaek, Thomas Heide and Gitte Madsen) saw that the world was moving towards a project-run society and that people needed new skills, competencies and mind-sets in order to flourish in this new global order. Other incentives for starting Kaospilot included much discussed analyses of what could have been done better in Moscow in 1989, and what kind of education could have supported this group in their ambitious project. The group also pondered and analysed how they could have been better negotiators with the KGB and how, ultimately, they could teach these skills to other students.

The rock concert organised in Moscow represented, in hindsight, the start of Kaospilot. The organising team faced considerable obstacles with the local authorities as well as numerous other organisational challenges. Areas of discussion turned to the fact that that there was no school or education program that would prepare you for an experience like organising a rock concert in Moscow during the Soviet Union era or taught you skills like negotiating in difficult situations or organising an event in unusual contexts. These were some of the guiding ideas at the time of Kaospilot's founding.

The school has been built to embrace change and to facilitate the finding of skills needed to act successfully in an always evolving environment. The school also has a strong societal focus. One bold slogan proclaims, 'we want to be the best school for the world'. Simon Kavanagh explains the premises and targets of Kaospilot thusly, 'I mean changing the whole game, not just parts of it. Holistic and systemic solutions are core to everything. Systemic means to me that the system is made selfaware of the challenges it is dealing with' (Simon Kavanagh, personal communication, October 2015). 
There must have been some kind of signal with respect to the decline of the Soviet Union when Uffe Elbaek and compatriots were organising the rock concert two years before the December 1991 dissolution. The group, however, did not see this geopolitical earthquake coming and Kavanagh says that training Kaospilot students to recognise weak signals both in society and in the markets is an important part of the education. This is called Listening Louder in Kaospilot language. According to Kavanagh, 'It is important to analyse what is the arising need that the weak signal describes. With the right competencies, recognising weak signals can be catalysed into action' (2015).

Kaospilot grounds its business thinking in the widely used 3P Model (People, Profit, Planet) originated by John Elkington in $1994 .^{2}$ According to Kavanagh:

We are a social entrepreneurial school, but we don't force students to be social entrepreneurs. Ironically, being sustainable and responsible also improves your businesses bottom line. So even if a student comes to the school with a corporate business mind, they might notice that purpose-driven business creates more money. (2015)

At the time of this writing, the school is hosting its 23rd class of Kaospilot students. Each year, a new team of 38 students begin their learning journey. While visiting the school, it became evident that the students had a remarkably strong team spirit. It seemed that the students also identified themselves strongly with their designated teams. 'I am from team 22' was, for example, an expression heard several times during the visit.

Naturally, the school has both changed and evolved across the years. Nevertheless, some fundamentals have remained stable. Founder Uffe Elabek attested to this continuity, 'although the curriculum has changed radically today-luckily-from when the school was founded over 20 years ago, in my eyes some things have not changed; not least the special professional and cultural mind-set that is unique to Kaospilots' (Windeløv-Lidzélius 2012). Alumnus David Jul agrees:

The way the community is built is one of the fundamentals. It is part of the tradition that we nurture our community and take responsibility for it. (David Jul, personal communication, October 2015) 


\section{An Alternative for Academia-Educating Change Agents}

Kaospilot has ambitious achievement targets and during the visit, the interviewees were asked what being a change maker meant to them. There were some similarities that were present in most of the answers. These oft-repeated statements included building of self-knowledge, having a vision of the kind of change you want to see take place, the ability to start working even if you cannot envision the full picture of the project in hand, and finally, having a strong trust in one's ability to act successfully towards a grand overarching goal.

During the visit, Kaospilot alumnus Jul reiterated that it is more important for the school to keep trying to figure out what being a change agent is about, than in actually finding the answer. The following quote from Kaospilot principal Christer Windeløv-Lidzélius describes the teaching philosophy of the school and also reveals what is expected form students and what kind of qualities are considered important in order for the students to build their career as a change agent:

Our fundamental understanding of how we teach people is to help them to teach themselves. There are certain things you can teach, but only so much. What we do essentially is to curate the learning journey for each person individually. The belief is that our students are already creative. They bring their talents and their ideas with them. Besides, we strongly believe the people who come to our school are self-motivated and selfdriven, and that they need to be that, in order to pursue their goals and their values. In order to be a successful and productive Kaospilot student, you have to be your own teacher. Our students who enroll at this program are not empty vessels in which we pour certain things and thoughts in their heads. (Kerstin 2015)

First-year student Paajanen stresses here the importance of having the skill to get other people engaged and motivated when working towards a change. It is important to have a strong vision, but in addition '...there is the action part. You need to actually get people working towards that change' (Anu Paajanen, personal communication, October 2015).

Pete Sims, team leader and curriculum designer at Kaospilot, in pondering the question of change agency, points out two components and notes that having a vision of change does not grow in a vacuum: 
One, is to have personal agency and two, is to connect to something bigger than yourself. Sometimes the trap is that people think that 'I have to first focus on myself', 'find myself', and 'then I can go and change the world'. If you have something you need to work on, some issue, then that makes sense, but I don't think you become yourself until you get beyond yourself. Doing something that is bigger than yourself is the key. (Pete Sims, personal communication, October 2015)

Kis Jakobsen, Head of Studies, adds that an 'enterprising leader' knows their place in the community they are living and working in. Likewise, they also have language, networks, meaning and direction, in addition to the necessary skills and competencies.

So, what then are these skills and competencies? David Jul proposes that it is necessary to have knowledge about how the system or organisation you are trying to change actually works. Jul further emphasises that learning from the past is important in the sense that sometimes, in the midst of the innovation hype, we forget to look back and learn from what has already been done.

From the author's perspective, this all sounds quite demanding. Are Kaospilot students somehow untouched by the anxiety that uncertainty causes people? The answer must be 'of course not', but Jul considers that maybe they are a little bit better with coping with and even embracing uncertainty. To that end, the Kaospilot program has been built so that it causes anxiety in terms of approaching and analysing the big philosophical questions in life.

Kis Jakobsen adds his weight to this argument and explains that often during the third year of their studies, when a sizeable portion of the year goes into students' final projects, students enter a phase when they start asking themselves existential questions and questioning their choices:

We even congratulate the students for that because we see it as a very natural phenomenon and it also means that they are going through a personal growth period that many people end up facing only in their forties or even later in life. These students ponder the big questions at an early stage of their life: what do I actually want to do with my life and how do I want to spend this life I have? (Kis Jakobsen, personal communication, October 2015) 
Raising the ambition-level and capacity of students is considered to be an important part of the Kaospilot pedagogy. Simon Kavanagh says that as an educator you have to be clear about the level where the students are, and where they want to go, and where you, as an educator and want them to develop. 'You have to be demanding enough' (Simon Kavanagh, personal communication, October 2015, he emphasises). The founder of the school, Uffe Elbaek, talked about the same issue at an event in Helsinki in May 2016, 'You have to be demanding enough so that the students reach their potential, but there is a fine line in making the students break down with over-pressure.'

\section{How Can We Start Educating Change Agents Earlier?}

When asked about the creation of Kaospilot's close-knit community, Kavanagh says, 'It's about creating a learning space that is intimate and personal. You need to have a stake in your teammates and in the community. Creating an intense, rigorous training space is difficult to do at scale, it needs to be done based on the needs of a specific group' (2015).

This close-knit community is not something you can create in a day, as it requires the constant development and commitment of the people involved in it. Students spend a lot of time with their own team. The team consists of students that start their studies together. Building a close-knit community and a sense of belonging is one of the fundamentals at Kaospilot. It is a good grounding for creativity and for the courage to experiment. In the first days of their studies, the new Kaospilot students go out to the countryside and spend a couple of days there at a culture boot camp, where the cornerstones for the three-year co-operation program are laid down.

'Each year's class has, in a way, their own microcosm,' states first-year student Anu Paajanen. 'My class has a very empathic culture, whereas the class that started the year before has a culture of questioning everything'. At the beginning of our studies, the team leaders said to us that it is 'your class's culture' so it is your responsibility to develop in the direction you want to (Anu Paajanen, personal communication, October 2015). She continues:

The school has Wednesdays off, so each year's class can do what they want on this particular day. We decided to have them as team days where we concentrate on developing our team work. We created a team culture 
council, because we noticed that we had been discussing our values quite a lot, but they were not being emphasised much in everyday life. We wanted to do something about it, and now the class members can suggest different kinds of activities to the council. This approach is also simultaneously about practicing how you create and lead an organisational culture. (2015)

While interviewing various individuals at Kaospilot, questions arose about how we could, as a society, start educating or empowering societal change agents earlier than when students enter higher education. The interviewees, upon reflection, agreed that if a student has learned for 10-12 years that being a good student means being a well-behaving listener who makes no mistakes, then the educational system has 'failed'. Not least, there is a lot of work to be done before these students trust that there are not necessarily any right answers, and the best outcomes might come by first randomly bouncing around thoughts and ideas within a team. So, in that sense, there might first be work to do in convincing students that their own ideas and thoughts are valuable and can have a beneficial impact on others.

What could be done differently in an elementary school? According to the interviewees, having a very holistic view of education is important. It is not only about learning different skills and learning to use different tools, but about training your mind-set, being empowered to take action and not only analyse different phenomena. Also, a strong focus on personal growth and building self-knowledge is essential. Adding meditation and concentrating on personal growth is still something quite rare in traditional school systems.

Creating a well-functioning culture of critique (or feedback) is one of the essential prerequisites at Kaopsilot. Student Paajanen believes that working on giving feedback in a classroom or in any other type of team or organisation is very beneficial. The attitude in Kaospilot is that feedback is a gift and the only way to learn how your decisions affect others. With a functioning feedback culture, students can grow their self-knowledge and teamwork skills. One tool to help create constructive feedback mechanisms is the Johari Window model that helps students analyse the blind spots in their communication style. The Johari Window is a two by two matrix with questions created by two psychologists, Joseph Luft and Harrington Ingham, in 1955.

One frequently used technique at Kaospilot is the daily check-in and check-out practices where students gather in a circle and reflect on their 
expectations, hopes and concerns. This same technique is used in project work that students do as part of their studies. The most crucial part for the project to succeed, however, is considered to be the very beginning, how it is initiated. To that end, the students might even do a pre-project where they create a basis for the team dynamics and concentrate on the goals and objectives of the project at hand. There is an undeniable logic to this: before the actual work begins, the students want to understand each team member's strengths, weaknesses and style of working. At this point, the team puts effort into understanding both the different professional profiles present in the team and the different communication styles. Paajanen argues that this way it is easier to understand why people act the way they do, and it is easier to solve conflicts, or indeed even prevent them. After a year of studying at Kaospilot, she says that she has more understanding of how differently people work and how she herself co-operates with her colleagues and how her way of working impacts others.

During a project, some teams might schedule one day a week to tasks that involve evaluation and feedback. A critic might argue at this point that it would seem that all the time at Kaospilot passes on mere reflection while no actual work is done. Paajanen disagrees with this critique and says that the time is used very effectively, and a lot is done when the team shares a direction and has communal feeling of a common mission. It has been noted by numerous experts that there are numerous wasted learning possibilities, both professional and personal, when people rush into their next assignment or project without reflecting on what went well and what should have been done better regarding the recently completed tasks. 'How, for example, did the team deal with mistakes or challenges? And what did the team do well in the planning phase and was the chosen strategy optimal? Evaluating these questions, together with the team, is a very educational experience,' says Kavanagh (Simon Kavanagh, personal communication, October 2015).

One Kaospilot student explained that an important part of the education was learning different practical techniques and developing a mindset. Examples of this include how the students facilitate a brainstorming session, start finding solutions to complex challenges, managing creative processes, learning ways to get other people engaged, analysing trends and tapping what they are doing into the bigger picture of what is going on in the world. It could be argued that these are things that you could be taught at any primary or secondary school. It is about learning to take 
responsibility for your education and learning that you can be influential. Similar kinds of learning philosophies can be applied to different age groups, from primary school children to retired people.

\section{KaOSPILOT's WaYS OF WORKING}

Described below are a list of different practices that showcase the Kaospilot way of operating. An organisational culture is always unique and dependent on the individuals and their dynamics and the atmosphere they create as well as different structures-both formal and informal and visible and invisible. By looking at different daily practices, we can understand aspects that contribute to the unique organisational culture of Kaospilot.

\section{Finding Mentors and Establishing a Sparring Network}

The students are encouraged to find mentors to support their professional growth. Students also work together with team leaders or other staff members at Kaospilot. They can ask for sparring with anyone from the organisation if they believe that that individual would have valuable insights related to their project. The staff then could be considered as a network of sparring partners for the students.

\section{No Tests}

There are no traditional tests where you simply write down what you have read, but following longer projects, students give presentations and produce reports for their team leaders and colleagues. Even though the project might have 'failed', the students responsible for the project can still receive a high grade, if they succeed in analysing and documenting why they believe the project 'failed' and what they learned from it. Selfreflection and personal growth is once again an underlying theme that supports the substance experience that students gain. Presentation skills are essential in order for students to get their message heard and understood and students need to have explicit possibilities to train their presentation skills.

Anu Paajanen explains that students receive certain reading lists and some concepts are expected to be understood. This can be done by reading a book, watching a video and listening to podcasts or audiobooks. 
The format is irrelevant as long as the students gain a beneficial understanding of the material.

\section{Team Leaders and Outside Lecturers}

All three classes have their own team leaders. 'The role of the team leader is many fold. Their tasks involve guiding, coaching, planning the curriculum and being really out there for the students. There is no position like this in the university world,' states Kavanagh (Liam Kavanagh, personal communication, October 2015).

The great majority of the lectures and workshops are held by outside experts. During its 25-year history, Kaospilot has created a global network of experts and lecturers. Bringing various voices and experts to the school is one way to keep the intellectual foundations of the school in constant development.

\section{The Physical Space and Learning Environment}

The building Kaospilot occupies is more like an office building than a traditional school building. The staff and students call it the 'home base'. Each year's class has their own space that they manage (Figs. 12.2, 12.3 and 12.4).

Alumnus David Jul says that what is important to notice at Kaospilot is that the students are part of a professional network from day one of their studies. They do projects for clients and learn how to deal with people from different backgrounds, positions and sectors. It is a different kind of approach to academia, where on their last day they receive a diploma that states that they have graduated and can now be seen as a professional.

When I visited Kaospilot in October 2015, the first-year students were working on their first project. It was assigned from Doctors Without Borders and the assignment was to find ways to increase the number of volunteers by approximately 6000 people. This was a follow-up project from the three-day entrance exam, where the applicants also worked in teams with an assigned project. Doctors Without Borders had chosen the most appealing results for a follow-up development phase.

The first project that the students face is a follow-up project from the entrance exam. They are not given any guidance on project management or substance issues related to the project. The students, simply, are expected to figure out essentially everything on their own. 


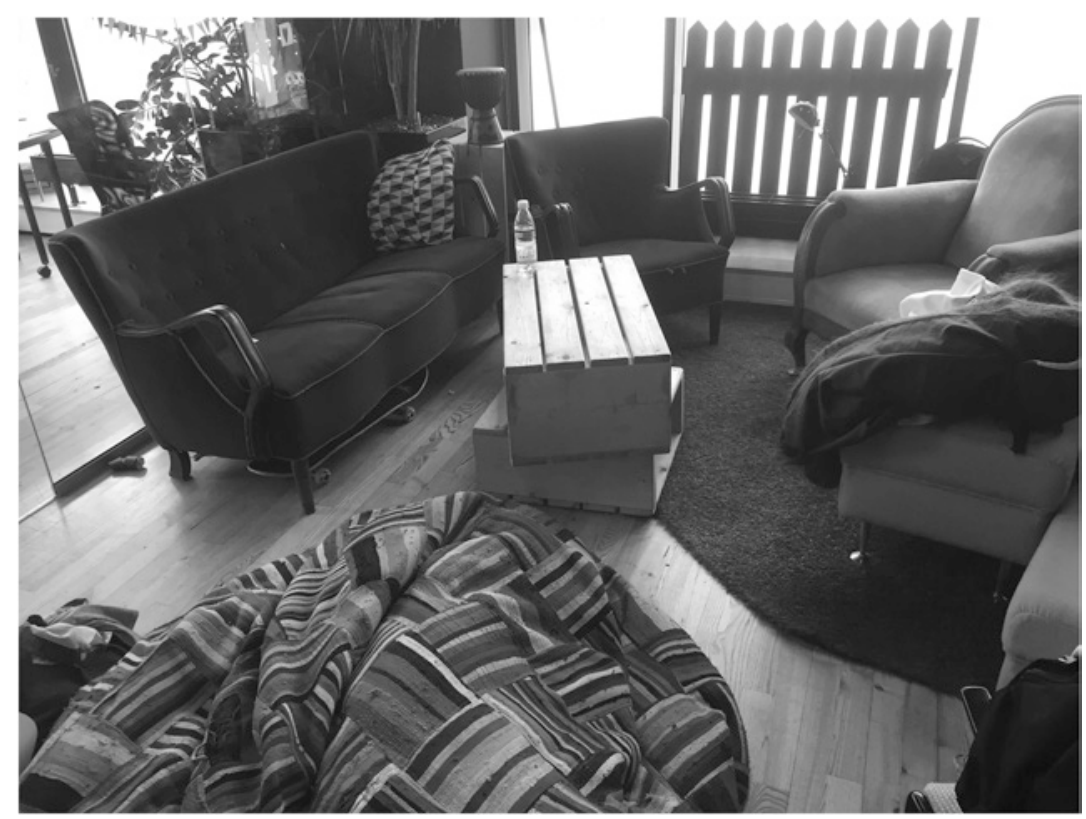

Fig. 12.2 Inside Kaospilot

The only thing that prepares them for the project, given to them by the school itself, is some basic information related to design thinking. The rationale behind this deep-dive is that upon completion of the project, when project management tools, feedback mechanisms etc. are taught, the students have experiences to reflect upon. According to Kavanagh, this 'thrown-in-the-deep-end' type of situation creates considerable frustration for the students, but also serves as a tremendous learning experience.

\section{Outpost}

In the fourth term, i.e. spring of the second year of their tenure, Kaospilot students embark on what they call an 'outpost'. It is a fourmonth study period abroad, during which the student works on a change target, chosen together with the local community. The goal for the outpost is to apply what the students have learned, into a different cultural 


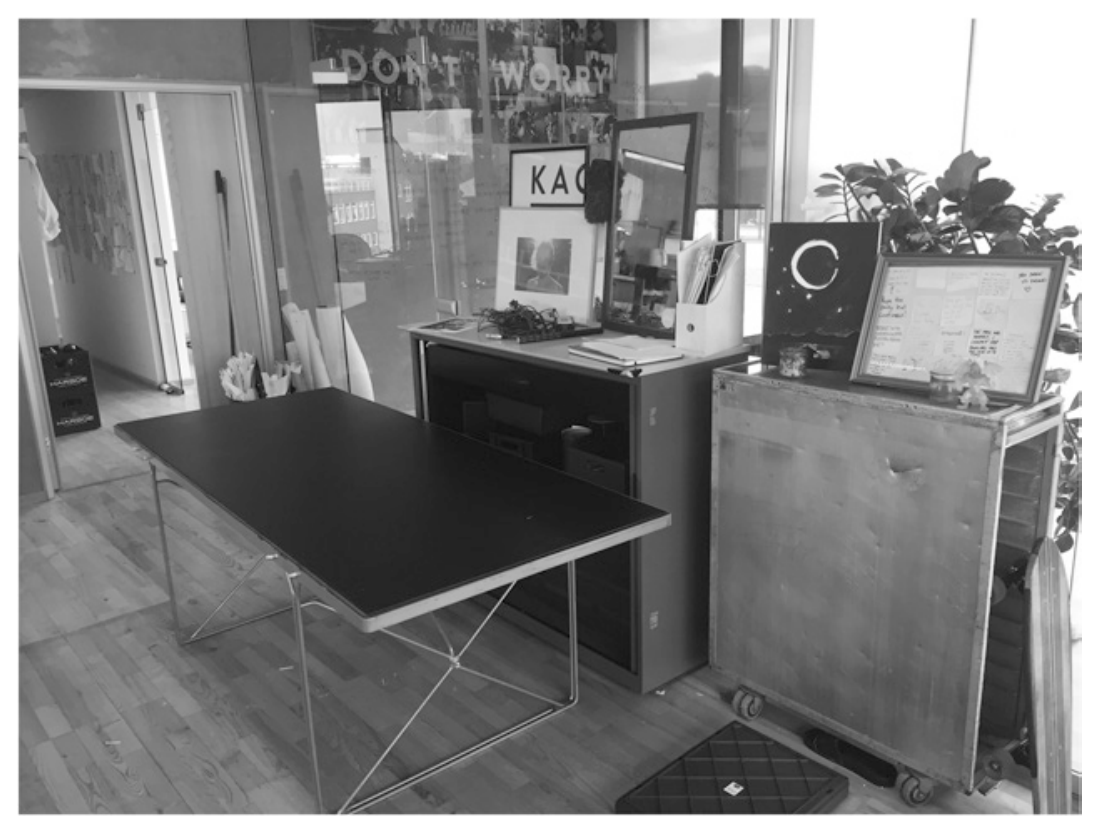

Fig. 12.3 Inside Kaospilot

context, to create an organisation from scratch and to co-ordinate around 10 projects under the organisation they have started. An important reason why the outpost is both conceived and implemented is to give the students an experience of what it is like to work in a context that is out of their comfort zone.

Previous Kaospilot outposts have been organised in Bogota, Durban, Vancouver and Cape Town, for example. The final year of studies is fully focused on the individual student's own business idea and personal project.

\section{To What Is Kaospilot an Answer?}

To what is Kaospilot an answer? What has been missing from, or has otherwise gone wrong in mainstream, traditional higher education? At Kaospilot, there is a slogan that says, 'Learning, not performing.' This slogan quite nicely sums up the issues and challenges in mainstream 


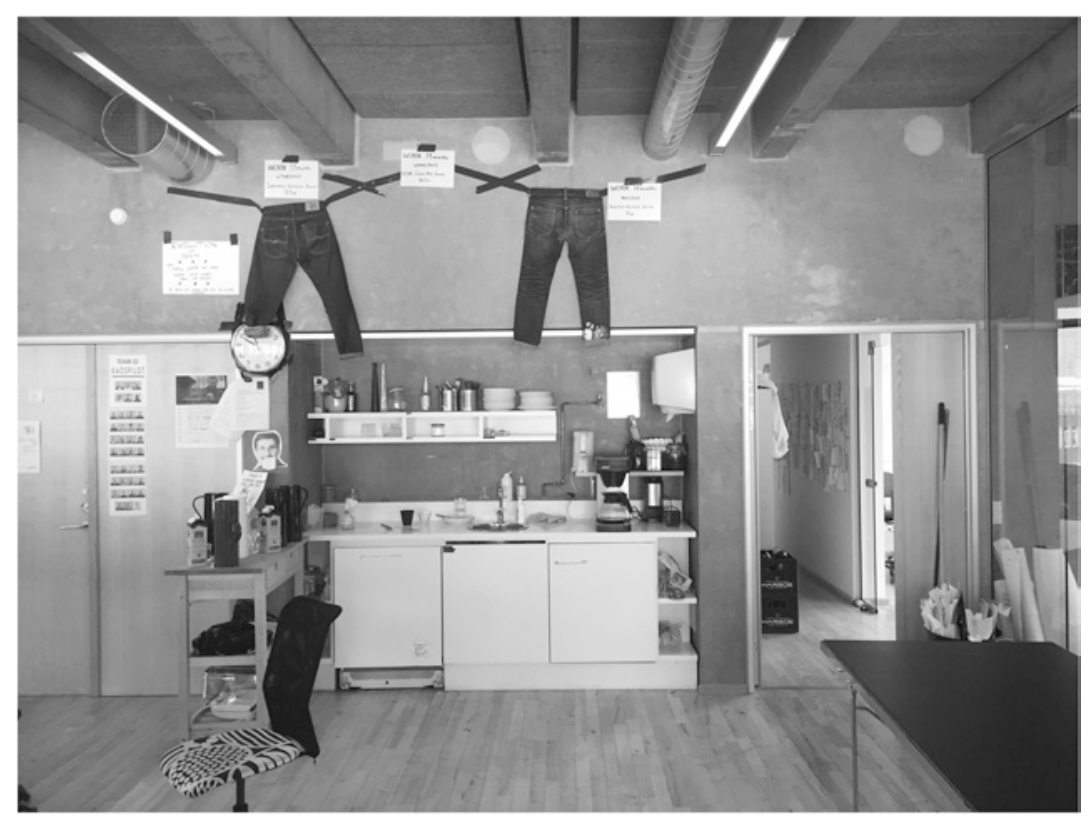

Fig. 12.4 Inside Kaospilot

higher education institutions: the focus on external motivational aspects like performing well in tests or meeting accreditation criteria. Anu Pajanen argues that a key point in Kaospilot's philosophy is clear that failing, as well as not knowing or understanding, are both allowed and even encouraged. These are considered the keys to developing the student's thinking. Some Kaospilot students have dyslexia (characterised as trouble with reading, despite normal intelligence) and across their entire school career felt that they were 'stupid'. At Kaospilot, the teaching methods are versatile and there is no 'right' learning method.

Taking into consideration the fact that Kaospilot has a small number of students and relatively high tuition fees, Kis Jakobsen states that Kaospilot is aiming to educate high-potential individuals. From Kaospilots' perspective, the understanding of who is a high-potential individual might just not be the traditional one, not least because of the lack of academic and test-based achievement. 
The Kaospilot curriculum has been built on four competences: subject competence, relationship competence, change competence and action competence. At the heart of these cornerstones of the curriculum are the creation of value for self and others. The Kaospilot curriculum defines the school's values to be those of courage, curiosity, empathy, lightness, patience, humility, generosity and toughness.

Prior to her studies at Kaospilot, Paajanen studied social sciences at The University of Helsinki. She started to ponder her future path in life after graduation and felt it was difficult for her to specify what she had to offer for an employer, even though she could provide both work and academic experience. After studying for a year at Kaospilot, her feeling could not be more different. 'I was ready to consult organisations after the first month at Kaospilot,' she says with a smile. 'Through different client projects you gain practical experience, self-confidence and networks. When you graduate, you know what you can do and what your strengths are. Part of the reason is that during the studies we concentrate on asking why-questions and analysing meaning and values. This is not present in many higher education institutions,' Paajanen observes (Anu Paajanen, personal communication, October 2015).

\section{ConClusion}

Returning to Sitra's sustainable well-being framework and considering the themes of adjusting to planetary boundaries, climate change and limited natural resources, the author has a sense that if one is concentrating on ecological sustainability, it is worthy, but is not the only focus of the work of change agents.

The primary aspect of holistic well-being in Kaospilot's educational system is to provide the tools and frameworks for the student so that they can create a mind-set that allows them to act in complex situations and strengthen their competencies, both as an individual and as an entrepreneur. Furthermore, students are supported in finding a career path where they can do meaningful work that is personal, but also beneficial for the rest of society and the planet in its entirety.

Often, traditional university programs are criticised for focusing only on subject matters and having a narrow scope when it comes to working with the complex ways in which people learn (not focusing enough on teaching students how to communicate or apply what they have learned). 
Students can too easily get 'drowned' in information and the only valid indication of success is how well you score in tests and exams. Kaospilot has gone in the other direction and focuses on how things get done, i.e. how you start, facilitate and manage a change process and how you create effectiveness in practice. Having a more holistic understanding of learning where meta-learning, skills, character and knowledge are combined, can be said to be aim of a Kaospilot education.

Kaospilot has, with its own operations, modelled how to move from the culture of working alone in subject silos, to a culture where it is understood that change happens through collaboration, co-creation and sharing. Start-up hype has created incubator and entrepreneurship communities in universities around the world. As a result, the understanding and excitement of co-creation, experimental culture and design thinking has spread. This is one of the reasons why Kaospilot is not as alternative or 'radical' now as when it started in 1991. And this is positive. The interviewees for this case study acknowledged this and some of them were even pondering what could be the next level in terms of how Kaospilot could even more effectively challenge some of the recognised contemporary norms in educational institutions, and in society.

Kaospilot as an organisation has modelled the kind of skills, character and knowledge that is needed to succeed in the complex times we live in. One example of this is the changing role of a teacher from a lecturer to a co-learner, guide and facilitator of learning. This has been the mode of teaching in Kaospilot and is now strongly present, for example, in the new Finnish national core curriculum, an educational template that has received international recognition.

Those who founded and are currently operating Kaospilot have well anticipated and practiced the kinds of skills needed for our complex times of economic, political and societal uncertainty. We need this courage to help create a better world-and we need a world where this courage can be practiced and developed.

\section{Notes}

1. https://su.org/programs/global-solutions-program/.

2. https://www.economist.com/node/14301663. 


\section{REFERENCES}

Kerstin, L. (2015, September 11). Five Questions with Danish Design School Chief Christer Windeløv-Lidzélius. Forbes. Retrieved April 1, 2018, from https:// www.forbes.com/sites/berlinschoolofcreativeleadership/2015/09/11/fivequestions-with-danish-design-school-chief-christer-windelov-lidzelius/\#34fa70c2la0a.

Kurutz, S. (2016, September 17). Want to Find Fulfillment at Last? Think Like a Designer. The New York Times. Retrieved April 1, 2018, from https://www. nytimes.com/2016/09/18/fashion/design-thinking-stanford-silicon-valley. html.

OECD Better Life Index: Jobs. (n.d.). Retrieved July 3, 2018, from http:// www.oecdbetterlifeindex.org/topics/jobs/.

What Is the Alternative? (2017, February 28). Retrieved April 1, 2018, from https://alternativet.dk/en/about-us/what-is-the-alternative.

Windeløv-Lidzélius, C., \& Bauning, K. (2012). The Kaospilots 20/20. Aarhus: KaosPilots.

Young, Gifted and Held Back. (2016, January 23). The Economist. Retrieved April 1, 2018, from https://www.economist.com/news/leaders/21688856worlds-young-are-oppressed-minority-unleash-them-young-gifted-and-heldback. 
Open Access This chapter is licensed under the terms of the Creative Commons Attribution 4.0 International License (http://creativecommons.org/licenses/ by $/ 4.0 /$ ), which permits use, sharing, adaptation, distribution and reproduction in any medium or format, as long as you give appropriate credit to the original author(s) and the source, provide a link to the Creative Commons license and indicate if changes were made.

The images or other third party material in this chapter are included in the chapter's Creative Commons license, unless indicated otherwise in a credit line to the material. If material is not included in the chapter's Creative Commons license and your intended use is not permitted by statutory regulation or exceeds the permitted use, you will need to obtain permission directly from the copyright holder.

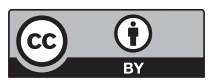

